\title{
Solanaceous Weeds as Possible Sources of Cucumber mosaic virus in Southern Illinois for Aphid Transmission to Pepper
}

H. A. Hobbs, D. M. Eastburn, and C. J. D’Arcy, Department of Crop Sciences, University of Illinois, Urbana 61801; J. D. Kindhart, University of Illinois, Dixon Springs Agricultural Center, Simpson 62985; J. B. Masiunas, Department of Natural Resources and Environmental Sciences, University of Illinois, Urbana 61801; D. J. Voegtlin, Illinois Natural History Survey, Urbana 61801; R. A. Weinzierl, Department of Crop Sciences, University of Illinois, Urbana 61801; and N. K. McCoppin, USDA-ARS, Crop Protection Research Unit, Urbana IL 61801

\begin{abstract}
Hobbs, H. A., Eastburn, D. M., D’Arcy, C. J., Kindhart, J. D., Masiunas, J. B., Voegtlin, D. J., Weinzierl, R. A., and McCoppin, N. K. 2000. Solanaceous weeds as possible sources of Cucumber mosaic virus in southern Illinois for aphid transmission to pepper. Plant Dis. 84:1221-1224.

Over 5,000 individual plants representing approximately 55 species from an area in southern Illinois where Cucumber mosaic virus (CMV) has been a major problem in pepper (Capsicum аппиит) were tested for the presence of CMV by enzyme-linked immunosorbent assay (ELISA). Representative ELISA-positive samples were checked by western blot tests to confirm virus-specific reactions. Nearly all of the infected plants detected were either Solanum ptycanthum (eastern black nightshade) or Physalis spp. (principally P. heterophylla, groundcherry). Over 1,000 pepper transplants and approximately 500 tomato transplants, collected prior to planting, were negative for CMV by ELISA. In aphid transmission (arena) experiments, all five aphid species tested were capable of transmitting CMV from nightshade to pepper: Aphis fabae subsp. solanella, Aphis gossypii, Myzus persicae, Rhopalosiphum padi, and Sitobion avenae. Aphis fabae subsp. solanella, A. gossypii, and A. nerii were able to transmit CMV from P. heterophylla to pepper. Aphis fabae subsp. solanella was commonly found colonizing nightshade from May through October in southern Illinois.
\end{abstract}

Cucumber mosaic virus (CMV) has been causing significant losses in southern Illinois bell pepper (Capsicum annuum) production since 1992. Fruit spotting and malformation and reduction in size and number of fruit caused by CMV infection have resulted in some farmers in the area ceasing to grow peppers.

CMV has an extremely wide experimental host range, infecting over 1,000 plant species in 100 families, including both dicots and monocots (7). Natural CMV weed hosts, which are potential virus sources for aphid transmission into crop fields, also belong to many plant families $(2,5,6,8,12,13,16,19,20)$. Some of these weed species are perennial and are likely to be important in the survival of CMV through periods when crop species are absent. CMV can also survive in the seed of at least 17 plant species (7).

At least 86 species of aphids have been reported as vectors of CMV (7). The virus is transmitted in a non-persistent manner

Corresponding author: Darin M. Eastburn

E-mail: eastburn@uiuc.edu

Accepted for publication 28 July 2000.

Publication no. D-2000-0907-01R

(C) 2000 The American Phytopathological Society with acquisition and transmission times of less than $1 \mathrm{~min}$. This means that plant species involved in CMV epidemiology may not necessarily be preferred aphid hosts. The most common aphid vectors of CMV are Myzus persicae and Aphis gossypii (14). Raccah et al. (15) implicated Aphis spiraecola (syn. A. citricola), A. gossypii, and $A$. craccivora in CMV infection of peppers in Israel. Sikora et al. (18) believed that $A$. gossypii was involved in CMV epidemics in tomato in Alabama in the early 1990s. Sixteen aphid species reported elsewhere as vectors of CMV have been found in southern Illinois (10,11). Lipaphis erysimi, Rhopalosiphum padi, R. maidis, Schizaphis graminum, and Aphis craccivora were the most commonly collected $(10,11)$.

The goals of our research were to test plant species for the presence of CMV to identify southern Illinois sources of the virus and to evaluate the ability of these plants to serve as sources for CMV transmission by aphids into pepper plants in aphid transmission (arena) experiments.

\section{MATERIALS AND METHODS}

Virus isolate. The virus isolate used in aphid transmission experiments was obtained by mechanical inoculation from field-infected nightshade (Solanum ptycanthum) to tomato (Lycopersicon escu- lentum) plants in the greenhouse. It was identified as CMV by reaction in enzymelinked immunosorbent assay (ELISA) to CMV-specific antibodies, and by symptomatology in inoculated pepper plants. The CMV isolate was maintained in pepper (Capsicum annuum), nightshade, and groundcherry (Physalis heterophylla) by mechanical inoculation and aphid transmission.

ELISA. Weeds for assay were collected in and around pepper fields. Weeds with and without virus-like symptoms were collected. Most weed species collected were symptomless. Weeds collected, as well as pepper transplants and cultivated plants grown nearby, were tested for CMV infection in 1996, 1997, and 1998 using ELISA (4) kits (Agdia 1000; Agdia, Inc., Elkhart, IN). Plant samples were kept on ice during transport, then stored at -20 or $-80^{\circ} \mathrm{C}$ until assayed. The protocol provided by the company for the Agdia CMV "compound direct ELISA" was followed. Absorbance at $405 \mathrm{~nm}$ was read using a Dynex MRX ELISA plate reader. The positive threshold value used was twice the absorbance value of the healthy controls. Representative plant samples that were positive for CMV using ELISA were retested using western blots.

Western blot technique. Sample preparation, acrylamide gel preparation, and running buffer for electrophoresis were as described by Sambrook et al. (17). Samples of 10 to $15 \mu \mathrm{l}$ were run for $1.5 \mathrm{~h}$ at 20 milliamps through a 5\% stacking and $12 \%$ resolving gel. After electrophoresis, band transfer was carried out as described by Cheng et al. (3). The procedure for the detection of CMV protein bands involved the following steps: a $6 \mathrm{~h}$ blocking step (5\% instant nonfat dry milk in PBS with agitation on a shaker at room temperature), overnight incubation with the primary antibody $(2 \mu \mathrm{g} / \mathrm{ml}$ anti-CMV polyclonal antibody, Agdia) under the same conditions, washing of the membrane three times in PBS, incubation with goat antirabbit alkaline phosphatase conjugate at a dilution of 1:1000 in PBS for $90 \mathrm{~min}$, and washing three times again. The membrane was then exposed to NBT/BCIP substrate until bands were clearly visible and the 
reaction stopped by rinsing with deionized water.

Aphid colonies. Aphid species were identified by D. Voegtlin, aphid taxonomist, and voucher specimens were deposited in the collection of the Illinois State Natural History Survey, Champaign, IL. Aphids used to establish colonies were collected from the following hosts: $S$. ptycanthum (nightshade) for Aphis fabae subsp. solanella, cucumber (Cucumis sativus) for A. gossypii, pepper (Capsicum annuum) for Myzus persicae, various graminaceous plants for Rhopalosiphum padi, $R$. maidis, and Sitobion avenae. The same hosts were used to maintain caged aphid colonies. Aphis nerii was collected from milkweed, Asclepias syriaca, and maintained in colony cages on shepherd's purse, Capsella bursa-pastoris.

Aphid transmission (arena) tests. Solanum ptycanthum, a species of nightshade, and Physalis heterophylla, a species of groundcherry, both found to be naturally infected with CMV in southern Illinois, were tested for their ability to serve as CMV sources in laboratory aphid transmission "arena" tests, using procedures slightly modified from Irwin and Ruesink (9). C. annuиm cv. X3R Camelot was used in both groups of tests as the transmission (or test) plant. Either intact, individual CMV-infected nightshade plants or cuttings from a CMV-infected groundcherry plant were placed in a water-filled tube in the center of and touching a ring of pepper seedling test plants in a 20 -cm pot. Nightshade plants were grown from seed in the greenhouse and mechanically inoculated with CMV. The groundcherry plant used in the study was collected from the field and mechanically inoculated with CMV in the greenhouse. Approximately 100 to 400 individuals of an aphid species were placed on the virus acquisition host plant. The pot then was covered with a cylindrical cage for 2 days to allow the aphids time to acquire CMV and move to the pepper test plants. If an aphid species remained very sedentary on the virus acquisition source plant or cutting, after 1 day the plant or cutting was removed from the water in the tube and allowed to wilt. If the aphid species crawled around actively during the first day, the virus acquisition source plant or cutting was kept in the water. The goal was to obtain maximum movement between virus acquisition source plants and test plants. After 2 days of access, some aphids were put in alcohol for later verification of identity, and the rest were killed with an insecticide. Pepper test plants were observed for symptoms and tested using ELISA after 3 weeks of growth in a greenhouse at $26^{\circ} \mathrm{C}$ with a 13 -h photoperiod.

\section{RESULTS}

Except for pepper, the vast majority of CMV-infected plants were Solanum ptycanthum (eastern black nightshade) and

Table 1. Number of plants ${ }^{\mathrm{z}}$ by species in or adjacent to pepper fields in southern Illinois tested for Cucumber mosaic virus using enzyme-linked immunosorbent assay (ELISA), 1996 to 1998

\begin{tabular}{|c|c|c|}
\hline Plant family/species & Common name & Number of plants tested \\
\hline \multicolumn{3}{|l|}{ Amaranthaceae } \\
\hline Amaranthus spp. & Pigweed & 168 \\
\hline \multicolumn{3}{|l|}{ Apocynaceae } \\
\hline Apocynum cannabinum & Hemp dogbane & 30 \\
\hline \multicolumn{3}{|l|}{ Asclepiadaceae } \\
\hline Asclepias syriaca & Milkweed & 169 \\
\hline \multicolumn{3}{|l|}{ Bignoniaceae } \\
\hline Campsis radicans & Trumpet creeper & 6 \\
\hline \multicolumn{3}{|l|}{ Caprifoliaceae } \\
\hline Lonicera sp. & Honeysuckle & 50 \\
\hline \multicolumn{3}{|l|}{ Caryophyllaceae } \\
\hline Cerastium sp. & Chickweed & 331 \\
\hline \multicolumn{3}{|l|}{ Chenopodiaceae } \\
\hline Chenopodium sp. & Lamb's quarters & 134 \\
\hline \multicolumn{3}{|l|}{ Compositae } \\
\hline Ambrosia trifida & Giant ragweed & 47 \\
\hline Eclipta sp. & Yerba de tajo & 21 \\
\hline Erigeron spp. & Fleabane & 148 \\
\hline Matricaria matricariodes & Pineapple weed & 40 \\
\hline Senecio glabellus & Butterweed & 90 \\
\hline Taraxacum officinale & Dandelion & 72 \\
\hline Xanthium sp. & Cocklebur & 39 \\
\hline Unidentified (without flowers) & & 166 \\
\hline \multicolumn{3}{|l|}{ Convolvulaceae } \\
\hline Ipomoea hederacea & Ivy-leaved morningglory & 104 \\
\hline Ipomoea purpurea & Common morningglory & 20 \\
\hline \multicolumn{3}{|l|}{ Cruciferae } \\
\hline Barbarea vulgaris & Yellow rocket & $52(1)$ \\
\hline Brassica sp. & Mustard & 60 \\
\hline Capsella bursa-pastoris & Shepherd's purse & 60 \\
\hline Lepidium $\mathrm{sp}$. & Peppergrass & 51 \\
\hline Rorippa sp. & Yellow cress & 51 \\
\hline Thlaspi arvense & Field pennycress & 6 \\
\hline \multicolumn{3}{|l|}{ Euphorbiaceae } \\
\hline Acalypha ostryaefolia & Three-seeded mercury & 53 \\
\hline \multicolumn{3}{|l|}{ Geraniaceae } \\
\hline Geranium sp. & Cranesbill & 40 \\
\hline \multicolumn{3}{|l|}{ Gramineae } \\
\hline Secale cereale & Rye & 117 \\
\hline Sorghum subglabrescens & Milo & 26 \\
\hline Triticum aestivum & Wheat & 69 \\
\hline
\end{tabular}

$\overline{{ }^{z} \text { Number of plants tested using ELISA. In parentheses, number of plants positive by ELISA and }}$ verified as virus-infected using western blot.

Physalis spp. (groundcherry), both belonging to the Solanaceae (Table 1). These infected plants ranged in symptoms expressed, from strong mosaic to barely visible mosaic or mottling. One tomato plant (Lycopersicon esculentum) in 1997 and one Barbarea vulgaris plant in 1998 were found to be infected with CMV (Table 1). Three of the species that were tested in very low numbers had virus-like symptoms: Campsis radicans, Desmodium spp., and Phytolacca americana. All were ELISA-negative for CMV, and were therefore presumed to be infected by other viruses. Some individual plants of various species belonging to the Compositae or Cruciferae gave apparently positive ELISA reactions, which were later demonstrated to be host-related false positives using the western blot technique. The $B$. vulgaris plant referred to above was verified as infected with CMV using the western blot technique. Approximately 1,000 pepper and 500 tomato transplants were tested by ELISA prior to potential field infection and were negative for the presence of CMV.

Physalis spp. plants were not identified to species in 1996 and 1997. Totals for the two years combined were 14 CMV-infected Physalis plants of 88 tested. In 1998, emphasis was placed on testing Physalis spp. in an area of southern Illinois (near Anna in Union County) in which $S$. ptycanthum was not common. Physalis plants tested in 1998 were identified as $P$. heterophylla (168 plants) and $P$. longifolia (29 plants). In that year, CMV was detected only in $P$. heterophylla: 30 of $168 P$. heterophylla plants were infected with CMV.

Seed was collected from $S$. ptycanthum greenhouse plants infected with CMV and germinated. None of 228 plants from these seeds were ELISA-positive for CMV.

All five of the aphid species tested transmitted CMV from $S$. ptycanthum to pepper (Table 2). A. fabae subsp. solanella was commonly found colonizing $S$. ptycanthum in southern Illinois from May 
Table 1. (continued)

\begin{tabular}{|c|c|c|}
\hline Plant family/species & Common name & Number of plants tested \\
\hline \multicolumn{3}{|l|}{ Labiatae } \\
\hline Lamium amplexicaule & Henbit & 15 \\
\hline Lamium purpureum & Deadnettle & 232 \\
\hline \multicolumn{3}{|l|}{ Leguminosae } \\
\hline Desmodium spp. & Tick trefoil & 12 \\
\hline Glycine $\max$ & Soybean & 131 \\
\hline Trifolium campestre & Hop clover & 51 \\
\hline Trifolium pratense & Red clover & 95 \\
\hline Trifolium repens & White clover & 95 \\
\hline Trifolium spp. & Clover & 427 \\
\hline Vicia sp. & Vetch & 73 \\
\hline \multicolumn{3}{|l|}{ Liliaceae } \\
\hline Allium sp. & Wild onion & 42 \\
\hline \multicolumn{3}{|l|}{ Onagraceae } \\
\hline Oenothera sp. & Evening primrose & 51 \\
\hline \multicolumn{3}{|l|}{ Phytolaccaceae } \\
\hline Phytolacca americana & Pokeweed & 4 \\
\hline \multicolumn{3}{|l|}{ Plantaginaceae } \\
\hline Plantago sp. & Plantain & 18 \\
\hline \multicolumn{3}{|l|}{ Polygonaceae } \\
\hline Polygonum sp. & Smartweed & 143 \\
\hline Rumex sp. & Dock & 97 \\
\hline \multicolumn{3}{|l|}{ Portulacaceae } \\
\hline Portulaca sp. & Purslane & 64 \\
\hline \multicolumn{3}{|l|}{ Rubiaceae } \\
\hline Galium sp. & Bedstraw & 42 \\
\hline \multicolumn{3}{|l|}{ Scrophulariaceae } \\
\hline Verbascum thapsus & Mullein & 15 \\
\hline Veronica sp. & Speedwell & 53 \\
\hline \multicolumn{3}{|l|}{ Solanaceae } \\
\hline Lycopersicon esculentum & Tomato & $202(1)$ \\
\hline Physalis spp. & Groundcherry & $285(44)$ \\
\hline Solanum ptycanthum & Nightshade & $549(32)$ \\
\hline Solanum carolinense & Horsenettle & 84 \\
\hline Solanum melongena & Eggplant & 89 \\
\hline \multicolumn{3}{|l|}{ Umbelliferae } \\
\hline Chaerophyllum sp. & Wild chervil & 35 \\
\hline \multicolumn{3}{|l|}{$\begin{array}{l}\text { Valerianaceae } \\
\text { Valom }\end{array}$} \\
\hline Valerianella sp. & Corn salad & 40 \\
\hline \multicolumn{3}{|l|}{ Vitaceae } \\
\hline Vitis spp. & Wild grape & 10 \\
\hline
\end{tabular}

Table 2. Aphid transmission (arena) experiments with Cucumber mosaic virus and with Solanum ptycanthum and Physalis heterophylla as virus acquisition hosts and pepper as the test host

\begin{tabular}{lcc}
\hline & \multicolumn{2}{c}{ Virus acquisition host } \\
\cline { 2 - 3 } Aphid species & Solanum ptycanthum & Physalis heterophylla \\
\hline No aphids (control) & $0 / 44^{\mathrm{y}}$ & $0 / 57$ \\
Rhopalosiphum padi & $6 / 28$ & $0 / 30$ \\
Rhopalosiphum maidis & $-\overline{\mathrm{z}}^{\mathrm{z}}$ & $0 / 30$ \\
Sitobion avenae & $3 / 28$ & $0 / 28$ \\
Myzus persicae & $4 / 43$ & $0 / 30$ \\
Aphis fabae subsp. solanella & $7 / 39$ & $9 / 60$ \\
Aphis gossypii & $36 / 42$ & $49 / 62$ \\
Aphis nerii & - & $19 / 32$ \\
\hline y Number of test plants infected as confirmed by enzyme-linked immunosorbent assay divided by \\
total number of test plants.
\end{tabular}

through October. Of the five aphid species tested, only A. gossypii transmitted successfully in all four individual trials in which $S$. ptycanthum was the virus acquisition host (data not shown). Infected pepper plants developed stunting and leaf deformation and were ELISA-positive.

In 1998 and 1999, colonies of A. nerii were observed on milkweed, Asclepias syriaca, in Union County in the areas where CMV-infected $P$. heterophylla plants were present. Because no aphid colonies ted in all three of the three trials in which it was included (data not shown). The remaining aphid species tested (R. padi, $R$. maidis, $S$. avenae, and $M$. persicae) did not transmit CMV when $P$. heterophylla was used as the virus acquisition host (Table 2).

\section{DISCUSSION}

Many weed hosts of CMV believed to be virus sources for crop infection have been reported. These have represented a number of plant families, including Asclepiadaceae, Caryophyllaceae, Cruciferae, and Scrophulariaceae in New York $(2,16)$; Commelinaceae (a monocot family), Compositae, Cucurbitaceae, Gerianaceae, Phytolaccaceae, and Solanaceae in Florida $(1,13,20)$; and Caryophyllaceae, Cucurbitaceae, Euphorbiaceae, Labiatae, Phytolaccaceae, and Solanaceae in Wisconsin and Illinois $(5,8,19)$. It is interesting to note that in the work of Doolittle and Walker (5) and Walker (19) in Wisconsin and Illinois, $P$. heterophylla was reported as a source for CMV infection of cucumber. In Arizona, $P$. wrightii was believed to be an important CMV source for aphid transmission to sugar beet (6).

In our study, with the exception of a single CMV-infected B. vulgaris (Cruciferae) plant, all sources of the virus were solanaceous weeds of the genera Solanum (species ptycanthum) and Physalis (primarily species heterophylla). The predominance of $S$. ptycanthum in Johnson County and of $P$. heterophylla in Union County suggests that the principal CMV weed hosts at the two locations could be different. Infected plants of both $S$. ptycanthum and $P$. heterophylla were mostly found on the edges of or within the boundaries of fields planted to peppers in previous years. Since weed populations in any given area are so large, particularly those of species with small plants like Cerastium spp. (chickweed), and because of the localized nature of virus infection of weeds in some cases, it is possible that infected plants of other weed species were missed during sampling.

Knowledge of CMV weed hosts in an area could be the basis for CMV control by their removal from in and around crop fields. Doolittle and Walker (5) and Wellman (20) reported good virus control following eradication of suspected CMV weed hosts.

We included seven of the 16 species of CMV-vectoring aphids reported to occur in southern Illinois $(10,11)$. The remaining nine species have not been tested with $S$. ptycanthum or $P$. heterophylla, using CMV isolates from southern Illinois.

The current results show that $A$. fabae subsp. solanella, the aphid commonly colonizing $S$. ptycanthum from May to October, is capable of transmitting CMV from that host. Although S. ptycanthum is generally considered to be an annual in the southern Illinois region, we found roots of 
the species that appeared to be perennial. $S$. ptycanthum has also been observed to be a short-lived perennial in Kentucky (M. Crotser, personal communication). A. fabae subsp. solanella could transmit CMV from $S$. ptycanthum to peppers in the spring.

$P$. heterophylla is a perennial. We found no aphids on this species. CMV is transmitted in a non-persistent manner, however, and efficient vectors, such as $A$. gossypii and $A$. nerii, could transmit CMV from $P$. heterophylla to peppers during movements through the area. A. nerii colonies were observed in mid-July on milkweed plants, which were growing in abundance in the vicinity of CMV-infected Physalis plants. A. nerii does not overwinter in southern Illinois but instead migrates from more southerly regions (11). It is possible that during these migrations some $A$. nerii individuals may land on infected Physalis plants, probe, and then fly to pepper plants and probe, before finally finding their milkweed hosts. However, whether the timing of $A$. nerii arrival in the area coincides with the likely time of initial CMV transmission to pepper, about midJune, remains to be determined.

\section{ACKNOWLEDGMENTS}

We thank Stephanie Crandall, Chester Jenkins, Lisa McKee, and Stephanie Waxler for technical assistance, and L.L. Domier for the use of his aphid transmission facilities. This research was partially funded by a grant from the Illinois Council on Food and Agricultural Research (C-FAR).

\section{LITERATURE CITED}

1. Anderson, C.W. 1959. A study of field sources and spread of five viruses of pepper in central Florida. Phytopathology 49:97-101.

2. Bruckart, W. L., and Lorbeer, J. W. 1976. Cucumber mosaic virus in weed hosts near commercial fields of lettuce and celery. Phytopathology 66:253-259.

3. Cheng, S. L., Domier, L. L., and D'Arcy, C. J. 1994. Detection of the readthrough protein of barley yellow dwarf virus. Virology 202:1003-1006.

4. Clark, M. F., and Adams, A. N. 1977. Characteristics of the microplate method of enzyme-linked immunosorbent assay for the detection of plant viruses. J. Gen. Virol. 34:475-483.

5. Doolittle, S. P., and Walker, M. N. 1926. Control of cucumber mosaic by eradication of wild host plants. U.S. Dep. Agric. Dept. Bull. No. 1461. 14pp.

6. Duffus, J. E. 1971. Role of weeds in the incidence of virus diseases. Annu. Rev. Phytopathol. 9:319-340.

7. Edwardson, J. R., and Christie, R. G. 1986. Cucumoviruses. Pages 143-215 in: Viruses Infecting Forage Legumes. J. R. Edwardson and R. G. Christie, eds. Monograph 14, IFAS, University of Florida, Gainesville.

8. Faan, H. C., and Johnson, J. 1951. The overwintering of cucumber mosaic virus. Phytopathology 41:1001-1010.

9. Irwin, M. E., and Ruesink, W. G. 1986. Vector intensity: a product of propensity and activity. Pages 13-33 in: Plant Virus Epidemics: Monitoring, Modelling, and Predicting Outbreaks. Academic Press, Australia.

10. Kagezi, G. H. 1997. Aphid species colonizing sweet peppers in southern Illinois and their importance as vectors of cucumber mosaic virus (CMV). Masters Thesis, University of Illinois, Department of Natural Resources and Environmental Sciences.

11. Kagezi, G. H., Voegtlin, D. J., and Weinzierl, R. A. The aphids (Homoptera: Aphididae) associated with bell peppers and surrounding vegetation in southern Illinois. Great Lakes Entomol. In press.
12. Kaper, J. M., and Waterworth, H. E. 1981. Cucumoviruses. Pages 257-332 in: Handbook of Plant Virus Infections and Comparative Diagnosis. E. Kurstak, ed. Elsevier/North-Holland Biomedical Press, Amsterdam.

13. Kucharek, T. A., Purcifull, D. E., Christie, R. G., and Perkins, K. D. 1998. The association of severe epidemics of cucumber mosaic virus in commercial fields of pepper and tobacco in north Florida with inoculum in Commelina benghalensis and C. communis. Plant Dis. 82:1172.

14. Palukaitis, P., Roosinck, M. J., Dietzgen, R. G., and Francki, R. I. B. 1992. Cucumber mosaic virus. Adv. Virus Res. 41:281-349.

15. Raccah, B., Gal-on, A., and Eastop, V. F 1985. The role of flying aphid vectors in the transmission of cucumber mosaic virus and potato virus Y to peppers in Israel. Ann. Appl. Biol. 106:451-460

16. Rist, D. E., and Lorbeer, J. W. 1991. Relationships of weed reservoirs of cucumber mosaic virus (CMV) and broad bean wilt virus (BBWV) to CMV and BBWV in commercial lettuce fields in New York. Phytopathology 81:367-371.

17. Sambrook, J., Fritsch, E. F., and Maniatis, T. 1989. Molecular Cloning: A Laboratory Manual, 2nd ed. Cold Spring Harbor Laboratory Press, New York.

18. Sikora, E. J., Gudauskas, R. T., Murphy, J. F., Porch, D. W., Andrianifahanana, M. Zehnder, G. W., Bauske, E. M., Kemble, J. M., and Lester, D. F. 1998. A multivirus epidemic of tomatoes in Alabama. Plant Dis. 82:117-120.

19. Walker, M. N. 1925. The relation of certain species of Physalis to the overwintering of the mosaic disease of cucumber. Phytopathology 15:733-744.

20. Wellman, F. L. 1937. Control of southern celery mosaic in Florida by removing weeds that serve as sources of mosaic infection. U.S. Dep. Agric. Tech. Bull. No. 548. 